\title{
ANALISIS MODAL KERJA DALAM MENINGKATKAN PERTUMBUHAN LABA BERSIH PT. PERKEBUNAN NUSANTARA IV MEDAN
}

\author{
Ihsan Rambe \\ Dosen Fakultas Ekonomi dan Bisnis Universitas Muhammadiyah Sumatera Utara \\ ihsanrambe@yahoo.co.id
}

\begin{abstract}
Working capital is the main factor driving the company's operations. The purpose of the study was to ascertain the management of working capital in the company, PT. Perkebunan Nusantara IV, was able to increase the net profit growth. The method used descriptive research with quantitative approach.The results of the analysis in 2011-2015 showed that the working capital in 2013 and 2015 decreased. Net profit growth in 2012,2013 and 2015 showed decreased too.
\end{abstract}

Keywords : Working Capital, Net Profit Growth

\section{A. Pendahuluan}

Setiap perusahaan yang bergerak dibidang industri dagang maupun jasa didirikan dan dijalankan dengan tujuan yang sama yaitu untuk menghasilkan laba dalam mencapai tujuan tersebut, setiap perusahaan dituntut untuk mengoptimalkan dan memanfaatkan potensi yang dimiliki perusahaan dengan baik, terutama berkaitan dengan pengelolaan modal kerja.

Modal kerja merupakan suatu elemen yang sangat penting dalam perusahaan yang harus dapat diperhatikan dalam pihak manajemen perusahaan dalam menjalankan kegiatan usahanya.Karena modal kerja sangat menunjang dalam menjalankan kegiatan usaha perusahaan terutama dalam meningkatkan laba bersih.

Modal kerja adalah dana-dana yang dimiliki oleh perusahaan seluruhnya akan digunakan untuk menghasilkan laba sesuai dengan usaha pokok perusahaan. ${ }^{\mathrm{i}}$ Modal kerja ini merupakan salah satu faktor yang penting dalam setiap kegiatan operasional usaha.Modal kerja yang dimiliki perusahaan haruslah memadai.Sebab salah satu kegagalan dari sebuah perusahaan adalah tidak mencukupinya modal kerja tersebut.Apabila perusahaan kekurangan modal kerja untuk kegiatan operasionalnya, maka besar kemungkinan perusahaan akan kehilangan pendapatan dan keuntungan. 
Demikian pula dengan halnya bila perusahaan melakukan investasi yang berkelebihan modal kerja, maka laba perusahaan akan berkurang karena kelebihan investasi dana tersebut dapat digunakan untukinvestasi lain yang dapat menguntungkan oleh perusahaan.

Modal kerja yang tinggi menunjukkan semakin besar kemampuan perusahaan memperoleh laba dan akan mempengaruhi tingkat profatibilitas yang tinggi

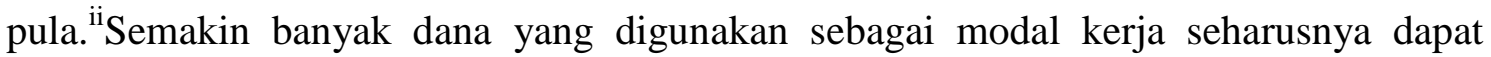
meningkatkan perolehan laba. ${ }^{\mathrm{ii}}$ Dengan demikian modal kerja merupakan suatu unsur yang diperlukan oleh suatu perusahaan karena modal kerja tersebut berpengaruh terhadap laba bersih yang dihasilkan dalam perusahaan tersebut, karena modal kerja perusahaan tidak akan berjalan kegiatan opersional sehari-hari dengan maksud memperoleh laba yang dinginkan.

Manajer harus selalu menilai apabila modal yang tertanam dalam aktiva lancar itu terlalu besar atau kecil, untuk menghindari ketidak tepatan modal kerja.Manajer keuangan juga harus melakukan pengawasan dan pengendalian terhadap penggunaan dana agar tidakterjadi penyimpangan. Penyimpangan ini dapat diketahui dari posisi keuangan yang tercermin dalam laporan keuangan perusahaan setiap akhir periode.Manajer keuangan perlu melakukan evaluasi terhadap modal kerja perusahaan untuk menilai keberhasilan perusahaan dalam kemampuannya untuk meraih laba tahun berjalan maupun pada tahun sebelumnnya.

Dalam penelitian ini,Penulis bermaksud untuk menganalisa Modal Kerja PT. Perkebunan Nusantara IV Medan dalam meningkatkan pertumbuhan laba bersihnya. Dari data awal yang penulis lihat dari laporan keuanganPT. Perkebunan Nusantara IV Medan tahun 2011 s/d 2015, khususnya pada laporan neraca dan laba rugi,terlihat bahwa laba yang diperoleh oleh perusahan masih tidak stabil atau masih mengalami peningkatan dan penurunan. Berdasarkan data yang diperoleh dari perusahaan berikut adalah perhitungan modal kerja dan laba bersih sebagai berikut:

Tabel 1. Modal Kerja dan Laba Bersih Pada PT Perkebunan Nusantara IV Medan

\begin{tabular}{|l|r|r|}
\hline Tahun & Modal Kerja (Rp) & Laba Bersih (Rp) \\
\hline 2011 & 273.022 .659 .357 & 890.866 .393 .008 \\
\hline 2012 & 367.326 .899 .485 & 697.428 .997 .083 \\
\hline 2013 & 95.878 .987 .360 & 433.344 .791 .637 \\
\hline
\end{tabular}




\begin{tabular}{|l|r|r|}
\hline 2014 & 147.803 .569 .771 & 752.363 .591 .531 \\
\hline 2015 & $(235.625 .580 .088)$ & 396.147 .720 .268 \\
\hline
\end{tabular}

Sumber data : PT Perkebunan Nusantara IV Medan

\section{B. Kajian Teori}

\section{Modal Kerja}

Pengertian modal kerja yaitu hak atau bagian yang dimiliki oleh pemilik perusahaan yang ditunjukkan dalam pos modal (Modal Saham), surplus dan laba yang ditahan, atau kelebihan nilai aktiva yang dimiliki oleh perusahaan terhadap seluruh hutang-hutangnya. ${ }^{\text {iv }}$

Ada 3 konsep modal kerja yaitu :

\section{Konsep Kuantitatif}

Menurut konsep ini modal kerja adalah seluruh jumlah aktiva lancar, berarti jumlah kas/bank + efek yang bisa diperjual belikan + piutang + persediaan

2. Konsep Kualitatif

Menurut kionsep ini modal kerja adalah selisih lebih jumlah aktiva lancar terhadap jumlah hutang lancar

3. Konsep Fungsional

Menurut konsep ini modal kerja adalah dana yang digunakan selama periode akuntansi untuk menghasilkan yang utama (current income) pada saat sekarang ini sesuai dengan maksud utama didirikannya perusahaan. ${ }^{\mathrm{v}}$

Sumber modal kerja suatu perusahan berasal dari:

1. Hasil operasional perusahaan, merupakan jumlah net income yang nampak dalam laporan perhitungan rugi laba ditambah dengan depresiasi dan amortisasi, jumlah ini menunjukkan jumlah modal kerja yang berasal dari hasil operasi nperusahaan.

2. Keuntungan dari penjualan surat-surat berharga (investasi jangka pendek). Keuntungan yang diperoleh dari penjualan surat-surat berharga ini merupan suatu sumber untuk bertambahnya modal kerja, sebaliknya apabila penjualan tersebut menjadi kerugian maka akan menyebabkan kekurangan modal kerja. 
3. Penjualan aktiva lancar merupakan sumber lain yang dapat menambah modal kerja adalah hasil penjualqan aktiva tetap, investasi jangka panjang dan aktiva tidak lancar lainnya yang tidak diperlukan lagi oleh perusahaan.

4. Penjualan saham atau obligasi merupakan untuk menambah dana atau modal kerja yang dibutuhkan perusahaan dapat juga mengadakan emisi saham baru atau meminta kepada para pemilik perusahaan untuk menambah modalnya, disamping itu perusahaan dapat juga mengeluarkan obligasi atau bentuk utang jangka panjang lainnya guna memenuhi kebutuhan modal kerja. ${ }^{\mathrm{vi}}$

\section{Pertumbuhan Laba Bersih}

Laba bersih adalah kelebihan seluruh pendapatan atas seluruh biaya untuk suatu periode tertentu setelah dikurangi pajak penghasilan setelah disajikan dalam laporan laba rugi.Para akuntan menggunakan istilah "net income" untuk menyatakan kelebihan pendapatan atas biaya adalah istilah "nett loss" untuk menyatakan kelebihan biaya atas pendapatan. ${ }^{\text {vii }}$

Pertumbuhan laba adalah perubahan laba pada laporan keuangan per

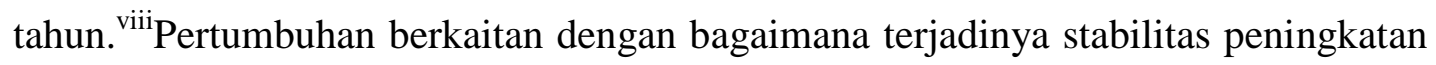
laba ditahun kedepan.Pertumbuhan laba yang diatas rata-rata bagi suatu perusahaan pada umumnya didasarkan pada pertumbuhan cepat yang diharapkan dan industri dimana perusahaan beroperasi.Pertumbuhan laba suatu produk sangat tergantung dari daur hidup perusahaan.

\section{Modal Kerja dalam Meningkatkan Laba Bersih}

Modal kerja dan laba bersih merupakan suatu kesatuan yang diperlukan dalam mencapai tujuan perusahaan.Semakin banyak dana yang digunakan sebagai modal kerja seharusnya dapat meningkatkan perolehan laba. Demikian pula sebaliknya, jika dana yang digunakan sedikit, laba pun menurun". ix

Laba (profit) yang tinggi akan mendukung kegiatan operasional secara maksimal. Tinggi rendahnya laba (profit) dipengaruhi banyak faktor seperti modal kerja karena modal kerja merupakan masalah utama yang akan menunjang kegiatan 
operasional perusahaan dalam rangka mencapai tujuannya yaitu menghasilkan laba (profit)". ${ }^{x}$

Dapat disimpulkan bahwa modal kerja merupakan suatu unsur yang selalu diperlukan oleh perusahaan karena modal kerja tersebut berpengaruh terhadap laba bersih yang akan dihasilkan oleh perusahaan karena dengan adanya modal kerja perusahaan dapat menjalankan aktivitas sehari-hari dengan tujuan utamanya yaitu untuk menghasilkan laba bersih.

\section{METODE PENELITIAN}

Penelitian ini dilakukan dengan metode deskriptif kualitatif.Penelitian ini dilakukan pada PT Perkebunan Nusantara IV Medan yang bergerak dalam bidang perkebunan yang berlokasi di JL.Letjen Suprapto No.2 Medan, Sumatera Utara No telepon (061) 4154666.

Dalam penelitian ini penulis menggunakan jenis data kuantitatif yang datanya diperoleh langsung dari perusahaan berupa data sekunder, yaitu dokumen laporan keuangan yang terdiri dari neraca, dan laporan laba rugi pada tahun 2011 sampai tahun 2015 dengan menggunakan teknik pengumpulan data dokumntasi

Defenisi operasional variabel yang bersngkutan dalam penelitian ini adalah sebagai berikut:

\section{Variabel Modal Kerja}

Variabel modal kerja yang digunakan dalam penelitian ini adalah modal kerja bersih.Modal kerja bersih adalah selisih antara aktiva lancar dengan kewajiban lancar. Rumus yang digunakan untuk menentukan modal kerja bersih adalah:

Modal Kerja Bersih $=$ Aktiva Lancar - Hutang Lancar

\section{Variabel Pertumbuhan Laba Bersih}

Pertumbuhan laba bersih adalah selisih laba bersih tahun berjalan dikurang denganlaba bersih tahun sebelumnya dibandingkan dengan laba bersih tahun sebelumnya dikalikan 100. Atau dengan rumus sebagai berikut:

Pertumbuhan laba bersih $=\frac{L B_{X}-L B_{X-1}}{L B_{X-1}} x 100$ 
Dimana :

LB = Laba bersih

LBx = Laba bersih tahun berjalan

LBx-1 = Laba bersih tahun sebelumnya

Adapun langkah-langkah yang dilakukan penulis adalah sebagai berikut:

1. Menggumpulkan data-data keuangan yang berhubungan dengan penellitian seperti data neraca dan laba rugi periode 2011-2015.

2. Mempelajari dan menghitung kembali data keuangan tersebut

3..Melakukan analisis pada modal kerja dan laba bersih perusahaan selama periode 2011-2015.

4. Melakukan interperensi dari data yag di dapat dari perusahaan.

5.Membuat suatu kesimpulan dari hasil penelitian tersebut.

\section{HASIL PENELITIAN DAN PEMBAHASAN}

\section{Analisis Modal Kerja}

Dari perhitungan modal kerja dengan menggunakan konsep modal kerja bersih maka modal kerja ini menggambarkan aktiva lancar perusahaan setelah dikurangi dengan kewajiban lancar perusahaan.

\section{Tabel II}

\section{Modal Kerja PT. Perkebunan Nusantara IV Medan}

Tahun 2011 - 2015

\begin{tabular}{|c|c|c|c|}
\hline Tahun & $\begin{array}{c}\text { Aktiva Lancar } \\
(\mathrm{Rp})\end{array}$ & $\begin{array}{c}\text { Kewajiban Lancar } \\
(\mathrm{Rp})\end{array}$ & Modal Kerja (Rp) \\
\hline 2011 & 1.731 .931 .950 .155 & 1.458 .909 .290 .798 & 273.022 .659 .357 \\
\hline 2012 & 1.968 .867 .355 .310 & 1.601 .540 .455 .825 & 367.326 .899 .485 \\
\hline 2013 & 1.634 .160 .727 .818 & 1.538 .281 .740 .458 & 95.878 .987 .360 \\
\hline 2014 & 2.092 .577 .404 .168 & 1.944 .773 .834 .397 & 147.803 .569 .771 \\
\hline 2015 & 1.527 .527 .005 .940 & 1.763 .152 .636 .028 & $(235.625 .580 .088)$ \\
\hline
\end{tabular}

Berdasaran tabel diatas dapat diketahui modal kerja perusahaan ditahun 2011 dan 2012 mengalami peningkatan modal kerja yaitu Rp 273.022.659.357 
menjadi Rp 365.326.899.485, kemudian ditahun 2013 modal kerja mengalami penurunan menjadi Rp 95.878.987.360 dari tahun sebelumnya, kemudian ditahun 2014 modal kerjamengalami peningkatan menjadi Rp 147.803.569.771 dari tahun sebelumnya, dan ditahun 2015 modal kerja perusahaan mengalami penurunan sampai menunjukkan nilai negatif yaitu $\mathrm{Rp}-235.625 .580 .008$.

Pada tahun 2011 dan 2012 modal kerja mengalami peningkatan dari Rp 273.022.659.357 menjadi Rp 365.326.899.485, juga diikuti dengan meningkatnya aktiva lancar tahun 2011 senilai Rp1.731.931.950.155 dan ditahun 2012 senilai Rp1.968.867.355.310. Hal ini disebabkan oleh kas das setara kas, piutang lain-lain, piutang antar badan hukum, persedian bahan baku dan perlengkapan, persedian hasil jadi, dan pajak dibayar dimuka. Namun kewajiban lancar juga mengalami peningatan yang disebabkan oleh pendapatan diterima dimuka, hutang antar badan hukum, dan liabilitas jangka pendek lainnya. Dimana total kewajiban lancar ditahun 2011 senilai Rp1.458.909.290.798 dan ditahun 2012 senilai Rp1.601.540.455.825. Walaupun kewajiban lancar mengalami peningkatan tetapi lebih besar aktiva lancarnya. Pada tahun 2013 modal kerja mengalami penurunan dari tahun sebelumnya ditahun 2012 modal kerja senilai Rp 367.326.899.485 dan ditahun 2013 senilai Rp 95.878.987.360. Aktiva lancar menurun disebabkan oleh kas dan setara kas, persedian barang jadi. Kewajiban lancar tahun 2012 Rp 1.601.540.455.825 tahun 2013 Rp 1.538.281.740.458,penurunan ini disebabkan oleh hutang pajak, pendapatan diterima dimuka, hutang antar badan hukum, liabilitas imbalan kerja jangka pendek,liabilitas jangka pendek lainnya. Hal ini yang menyebabkan modal kerja menurun.

Pada tahun 2014 modal kerja mengalami peningkatan dari tahun sebelumnya ditahun 2013 modal kerja senilai Rp 95.878.987.360 dan ditahun 2014 senilai Rp147.803.569.771. Aktiva lancar ditahun 2013 senilai Rp 1.634.160.727.818 ditahun 2014 senilai Rp2.092.577.404.168,dikarenakan oleh meningkatnya kas dan setara kas, piutang antar badan hukum, persediaan hasil jadi,pajak dibayar dimuka. Kewajiban lancar tahun 2013 senilai Rp 1.538.281.740.458 ditahun 2014 senilai Rp1.944.773.834.397, dikarenakan oleh hutang usaha, hutang pajak,pendapatan diterima dimuka,bagian liabilitas jangka panjang yang akan jatuh tempo, lialibilitas imbalan kerja jangka pendek. Walaupun 
kewajiban lancar mengalami peningkatan tetapi lebih besar aktiva lancarnya.Hal ini yang menyebabkan modal kerja mengalami peningkatan. Pada tahun 2015 modal kerja mengalami penurunan dari tahun sebelumnya sampai angka negatif, ditahun 2014 modal kerja senilai Rp147.803.569.771 dan ditahun 2015 senilai $\operatorname{Rp}(235.625 .580 .088)$. Disebabkan aktiva lancar dan kewajiban lancar ditahun 2015 menurun. Aktiva lancar ditahun 2014 senilai Rp2.092.577.404.168 ditahun 2015 senilai Rp1.527.527.005.940, dikarena oleh kas dan setara kas,piutang lainlain,persediaan bahan baku dan perlengkapan. Kewajiban lancar tahun 2014 senilai Rp1.944.773.834.397 dan ditahun 2015 senilai Rp1.763.152.636.028,dikarenakan oleh beban yang masih harus dibayar, hutang pajak,uang muka penjualan,liabilitas imbalan kerja jangka pendek, lialibilitas jangka pendek lainnya. Hal tersebut yang menyebabkan modal kerja tahun 2015 menurun sampai angka negatif.

Dari analisis diatas dapat dilihat bahwa perusahaan belum memadai modal kerja karena belum bisa melakukan operasionalnyayang ada didalam perusahaan dengan baiksehingga perusahaan tidak bisa menghasilkan yang baik karena modal kerja yang dihasilkan mencapai angka negatif.

\section{Analisis Laba Bersih}

Tabel III

\section{Laba Bersih PT. Perkebunan Nusantara IV Medan \\ Tahun 2011-2015}

\begin{tabular}{|c|c|c|c|}
\hline Tahun & Pendapatan & Beban & Laba Bersih \\
\hline 2011 & 2.529 .506 .964 .182 & 1.638 .640 .571 .174 & 890.866 .393 .008 \\
\hline 2012 & 2.573 .857 .412 .694 & 1876.428 .415 .611 & 697.428 .997 .083 \\
\hline 2013 & 2.309 .420 .181 .219 & 1.876 .075 .389 .582 & 433.344 .791 .637 \\
\hline 2014 & 2.780 .794 .950 .747 & 2.028 .431 .359 .216 & 752.363 .591 .531 \\
\hline 2015 & 1.881 .170 .360 .578 & 1.485 .022 .640 .310 & 396.147 .720 .268 \\
\hline
\end{tabular}

Berdasarkan tabel diatas dapat diketahui bahwa dari tahun 2011 sampai dengan tahun 2013 perusahaan tidak mampu menaikkan laba bersihsehingga 
mengalami penurunan. Dimana pada tahun 2011 laba bersih yang dihasilkan senilai Rp890.866.393.008,ditahun 2012 laba yang dihasilkan senilai Rp 697.428.997.083, dan ditahun 2013 laba yang dihasilkan senilai Rp 433.344.791.637. Sedangkan ditahun 2014 laba perusahan mengalami peningkatan kembali dari tahun sebelumnya yaitu senilai Rp 752.363.591.531, tetapi ditahun 2015 laba perusahan mengalami penurunan kembali dari tahun sebelunya yaitu senilai Rp 396.147.720.268.

Pada tahun 2011 laba perusahaan senilai Rp 890.866.393.008 karena pendapatan yang di peroleh lebih besar dibandingkan dengan beban yang dikeluarakan dalam kegiatan operasionalnya .Pendapatan yang diperoleh senilai Rp2.529.506.964.182, sedangkan beban yang dikeluarkan oleh perusahaan senilai Rp1.638.640.571.174.

Pada tahun 2012 laba perusahaan mengalami penurunan dari tahun sebelumnya.Walaupun pendapatan yang diperoleh meningkat tetapi beban yang yang dikeluarkan juga mengalami peningkatan. Laba yang diperoleh ditahun 2012 senilai Rp 697.428.997.083, dan pendapatan yang diperoleh senilai Rp2.529.506.964.182. Pendapatan meningkat dikarena oleh pendapatan penjualan dan harga pokok penjualan. Sedangkan beban yang dikeluarkan oleh perusahaan senilai Rp 1876.428.415.61, beban meningkat dari tahun sebelumnya dikarenakan oleh biaya penjualan, biaya administrasi, biaya bunga, taksiran pajak penghasilan.Hal ini yang menyebabkan laba tahun 2012 mengalami penurunan dari tahun sebelumnya.

Pada tahun 2013 laba yang diperoleh mengalami penurunan kembali dari tahun sebelumnya, laba yang diperoleh senilai Rp 433.344.791.637.Disebabkan kerena pendapatan yang diperoleh mengalami penurunan.Dimana penurunan tersebut terdapat pada penjualan menurun dan harga pokok penjualan juga mengalami penurunan.Total pendapat tahun $2012 \mathrm{Rp}$ 2.529.506.964.182 menjadi 2.309.420.181.219 ditahun 2013. Beban opersional yang dikeluaran perusahan untuk kegiatan sehari-hari juga mengalami penurunan ditahun 2012 senilai Rp1876.428.415.611 dan ditahun 2013 senilai Rp1.876.075.389.582. Dikarenakan oleh biaya usaha, taksiran pajak penghasilan.Pada tahun 2014 laba mengalami peningkatan dari tahun sebelumnya laba tahun 2013 senilai $\mathrm{Rp} 433.344 .791 .637$ 
ditahun 2014 Rp752.363.591.531. Hal ini disebabkan oleh Penjualan dan harga pokok penjualan mengalami peningkatan. Dimana total pendapatan tahun $2013 \mathrm{Rp}$ 2.309.420.181.219 ditahun 2014 Rp 2.780.794.950.747. Beban yang dikeluarkan oleh perusahaan mengalami peningkatan ditahun 2013 Rp1.876.075.389.582 ditahun 2014 Rp2.028.431.359.216. Dimana peningkatan tersebut terdapat pada biaya usaha, biaya bunga, taksiran pajak penghasilan. Pada tahun 2015 laba perusahaan mengalami penurunan dari tahun sebelumnya, hal ini dikarenakan pendapatan mengalami penurunan. Dimana penurunan tersebut disebabkan oleh penjualan dan harga pokok penjualan. Dimana total pendapat tahun $2014 \mathrm{Rp}$ 2.780.794.950.747 menjadi Rp 1.881.170.360.578 ditahun 2015. Beban yang dikeluarkan perusahaan juga mengalami penurunan yaitu terdapat pada biaya usaha, biaya bunga, taksiran pajak penghasilan.Dimana total beban tahun $2014 \mathrm{Rp}$ 2.028.431.359.216 menjadi Rp 1.485.022.640.310 ditahun 2015.Hal tersebut yang mengakibatkan laba mengalami penurunan.

\section{Analisis Modal Kerja dalam Meningkatkan Pertumbuhan Laba Bersih}

Berikut ini adalah data Modal Kerja dan Laba Bersih pada PT Perkebunan Nusantara IV Medan tahun 2011 sampai dengan tahun 2015.

Tabel 4. Modal Kerja dan Laba Bersih Pada PT Perkebunan Nusantara IV Medan

\begin{tabular}{|l|c|c|c|c|}
\hline Tahun & Modal Kerja (Rp) & Pertumbuhan (\%) & Laba Bersih (Rp) & Pertumbuhan (\%) \\
\hline 2011 & 273.022 .659 .357 & - & 890.866 .393 .008 & - \\
\hline 2012 & 367.326 .899 .485 & $0,34 \%$ & 697.428 .997 .083 & $-0,21 \%$ \\
\hline 2013 & 95.878 .987 .360 & $-0,73 \%$ & 433.344 .791 .637 & $-0,37 \%$ \\
\hline 2014 & 147.803 .569 .771 & $0,54 \%$ & 752.363 .591 .531 & $0,73 \%$ \\
\hline 2015 & $(235.625 .580 .088)$ & $-2,59 \%$ & 396.147 .720 .268 & $-0,47 \%$ \\
\hline
\end{tabular}

Berdasarkan hasil perhitungan diatas dapat diketahui bahwa modal kerja perusahaan dari tahun 2011 sampai dengan 2013 mengalami penurunan.Sedangkan laba bersih yang diperoleh perusahaan di tahun 2011 sampai dengan 2013 juga mengalami penurunan. Namun pada tahun 2014 modal kerja mengalami peningkatan dari tahun sebelumnya dan diikuti oleh laba yang mengalami peningkatan juga.Sedangkan ditahun 2015 modal kerja mengalami penurunan kembali hingga angka negatif dan laba bersih juga mengalami penurunan kembali dari tahun sebelumnya.

Pada tahun 2011 modal kerja yang digunakan oleh perusahaan senilai Rp273.022.659.357 dan menghasilkan laba bersih senilai Rp890.866.393.008. Tahun 
2012 modal kerja yang digunakan perusahaan senilai Rp367.326.899.485dan menghasilkan laba senilai Rp697.428.997.083. Tahun 2013 modal kerja yang digunakan oleh perusahaan senilai Rp95.878.987.360 dan menghasilkan laba senilai Rp433.344.791.637. Tahun 2014 modal kerja yang digunakan oleh perusahaan senilai Rp147.803.569.771 dan menghasilkan laba senilai Rp752.363.591.531. Tahun 2015 modal kerja yang digunakan mengalami penurunan menjadi $\operatorname{Rp}(235.625 .580 .088)$ dan laba yang dihasilkan senilai Rp396.147.720.268.

Penurunan modal kerja karena tingginya kewajiban lancar perusahaan yaitu pada hutang usaha, beban yang masih harus dibayar, hutang pajak,hutang jangka panjang yang jatuh tempo. Hal ini menunjukkan bahwa modal kerja yang digunakan belum memadai untuk menjalankan kegiatan operasional perusahaan.Ditahun 2013 dan ditahun 2015 penurunan modal kerja tersebut diikuti oleh penurunan laba bersih perusahaan. Sedangkan pada tahun 2012 dan 2014 modal kerja mengalami peningkatan, tetapi laba bersih ditahun 2013 mengalami penurunan, sedangkan ditahun 2014 laba bersih mengalami peningkatan. Dengan begitu modal kerja belum optimal dalam meningkatkan laba bersih perusahaan.

\section{E. KESIMPULAN DAN SARAN}

\section{Kesimpulan}

Dari analisis yang telah dilakukan oleh penulis, maka penulis mengemukakan kesimpulan berdasarkan perhitungan dari teori yang telah dikemukakan pada babbab sebelumnya. Adapun kesimpulan yang penulis kemukakan adalah sebagai berikut:

1. Selama 5 tahun dari tahun 2011 sampai dengan tahun 2015 modal kerja perusahaan mengalami fluktuasi setiap tahunya sampai di tahun 2015 modal kerja bernilai negatif. Modal kerja mengalami penurunan disebabkan oleh kewajiban lancar berjumlah lebih besar dibandingkan dengan aktiva lancar, khusunya pada hutang usaha dan hutang jangka panjang yang jatuh tempo.

2. Pada tahun 2011 sampai dengan tahun 2013 laba bersih perusahaan mengalami penurunan. Hal ini dikarenakan pendapatan/penjualan mengalami penurunan. Sedangkan ditahun 2014 laba bersih mengalami peningkatan, karena pendapatan/penjualan mengalami peningkatan dari tahun sebelumnya dan lebih 
besar pendapatan/penjualan dibandingkan dengan beban yang dikeluarkan oleh perusahaan untuk kegiatan operasional sehari-hari.

3. Dilihat selama periode pengamatan modal kerja perusahaan belum optimal dalam meningkatkan laba bersih perusahaan.

\section{Saran}

Berdasarkan kesimpulan diatas, adapun saran yang diberikan oleh penulis sebagai berikut:

1. Sebaiknya manajemen memanfaatkan assetnya secara maksimal dan mengalokasikan dana yang baik dan efesien dalam aktivitas perusahaan agar perusahaan memiliki kas yang cukup untuk biaya operasionalnya, karena penurunan laba bersih diantaranya berpengaruh oleh kebutuhan modal kerja tidak efektif.

2. Sebaiknya jumlah kewajiban lancar perusahaan jangan melebihi jumlah aktiva lancar perusahaan, karena jika hal ini terjadi ada kemungkinan yang akan terjadi bahwa perusahaan tidak mampu untuk membayar kewajiban lancarnya.

3. Disarankan agar perusahaan lebih efesien menggunakan modal kerja yang dimiliki oleh perusahaan sehingga dapat meningkatkan laba bersih yang akan dihasilkan oleh perusahaan, dan diharapkan perolehan laba perusahaan ditingkatkan dengan cara perusahaan dapat meminimalisir biaya-biaya yang dikeluarkan agar dapat mengimbangi keuntungan dan mengurangi kerugian. 


\section{DAFTAR PUSTAKA}

Abdul Rahim Harahap.(2015). Analisis Modal Kerja dalam Meningkatkan Laba Bersih pada PT.BAKRIE SUMATERA PLANTATIONS Tbk. Kisaran.

Agnes Sawir. (2005). Analisis Kinerja Keuangan dan Perencanaan Keuangan Perusahaan. Cetakan Kedua. Jakarta .PT. Rineka Cipta.

Amstrong, Gary \& Philip, khotler.(2002). Dasar- dasar Pemasaran Jilid 1Ahli Bahasa Alexander Sindono dan Benyamin Molan. Jakarta: Penerbit Prenhalindo.

Akhmad Khudzaifi (2017) dalam Sutrisno (2007).Manajemen Keuangan, Edisi Kelima. Ekonesia: Yogyakarta.

Bambang Riyanto. (2001). Dasar - Dasar Pembelajaran Perusahaan. Edisi Keempat. Yogyakarta.BPFT.

Brasmanto.(2008). Analisis Perputaran Aktiva Tetap dan Perputaran Piutang Kaitanya terhadap ReturnOn Asset pada PT.Pos Indonesia (PERSERO), Bandung ; Jurnal Ekonomi Unikom, VOL. 9, No.2, Hal 215-230.

Darmawan Sjahrial. (2009). Pengantar Manajemen Keuangan. Edisi Ketiga. Jakarta. Mitra Wacana Media.

Djarwanto.(2002). Pokok-Pokok Analisis Lporan Keuangan. Edisi Pertama. Yogyakarta: BPFE.

Fabozzi Frank J. (2000). Manajemen Investasi. Jakarta. Salemba Empat

Fuzuia.(2016). Analisis Modal Kerja dalam Meningkatkan Laba Bersih PT.Samudera Indonesia Tbk. Cabang Belawan.

Harianto dan Sudono.(2001). Perangkat dan Analisis Investasi di Pasar Modal Indonesia. Jakarta: PT. Buersa Efek Indonesia.

Harjito.(2007). Manajemen Keuangan Perusahaan. Cetakan Kelima. Ekonisia: Jakarta.

Hendry Saputro.(2015). Analisis Modal Kerja dalam Meningkatkan Laba Bersih pada PT. Mopoli Raya Medan.

Hendriksen Heldon S. (2000). Teori Akuntansi. Edisi Keempat. Jakarta. Erlangga.

Hery. (2013). Auditing (Pemeriksaan Akuntansi 1). Catatan Pertama. Jakarta: CAPS (Center Of Academic Publishing Service).

Jumingan.(2006). Analisis Laporan Keuangan. Jakarta: Bumi Aksara 
— (2011). Analisis Laporan Keuangan .Jakarta :Bumi Aksara.

Junita.(2016). Analisis Modal Kerja Bersih dalam Meningkatkan Profitabilitas pada PT.Razza Prima Trafo.

Kasmir.(2012). Analisis Laporan Keuangan. Edisi Pertama. Jakarta. PT. Raja Grafindo.

Martono dan D.Agus Harjito.(2001). Manajemen Keuangan. Yogyakarta: Ekonosia.

Martono dan Agus Harjito.(2007). Analisis Laporan Keuangan .Jakarta. Salemba Empat.

Mulyadi.(2002). Akuntansi Keuangan Intermadite.Jakarta. Salemba Empat.

— (2012). Akuntansi Keuangan Intermadite. Jakarta. Salemba Empat.

Munawar.(2007). Analisis Laporan Keuangan. Edisis Keempat. Yogyakarta.

Selpiana.(2016). Analisis Modal Kerja dalam Meningkatkan Laba Bersih pada PT. Pertani (Persero). Cabang Sumut.

Soemarso S.R. (2004). Akuntansi Suatu Pengantar. Edisi Kelima. Jakarta. Salemba Empat.

Stice dan Skunsen. (2009). Akuntansi Keuangan, Intermediate Accounting. Edisi Keempat Belas . Salemba Empat.

Supriyadi dan Fazriani.(2011). Pengaruh Modal Kerja Terhadap Tingkat Likuiditas dan Profitabilitas (Studi Kasus pada PT.Timah Tbk.dan PT. Antan Tbk.), Jurnal Ilmiah Ranggagading, Vol.11, No.1, Hal.1-11.

Widodo, Joko. (2008). Good Governance, Telah dan Dimensi Akuntalabilitas Birokrasi Pada Era Desentralisasi dan Otonom Derah. Surabaya: Instan Cendika. 
'munawir (2007, hal 116 )

"Djarwanto (2002:122)

iiiKasmir (2012, hal 251)

ivS. Munawir (2004, hal 19)

'Darmawan Sjahrial (2009, hal 103)

viMunawir (2007, hal 120)

vii Soemarso (2004, hal 44)

viiiFabozzi (2000,hal 881 )

ix Kasmir (2012,hal 251) “

×Brasmanto (2008) “ 